\title{
Korelasi antara Imunoekspresi p53 dan Respons Kemoterapi Neoadjuvan Regimen Fluororasil, Adriamisin, dan Siklofosfamid pada Karsinoma Duktus Payudara Invasif
}

\author{
Muhartono, Rizki Hanriko \\ Patologi Anatomi Fakultas Kedokteran Universitas Lampung
}

\begin{abstract}
Abstrak
Karsinoma duktus payudara invasif(KDPI) stadium IIIB perlu penanganan multimodalitas. Kemoterapi neoadjuvan (KN) diberikan untuk menurunkan ukuran dan stadium tumor agar dapat dilakukan operasi. Regimen KN yang biasanya digunakan yaitu fluororasil, adriamisin, dan siklofosfamid (FAS). Kemoterapi FAS bekerja dengan cara merusak deoxyribonucleic acid dan menginduksi apoptosis sel kanker. Terjadinya kelainan protein atau gen yang berhubungan dengan apoptosis ( 553 ) diduga mempengaruhi respons kemoterapi tersebut. Tujuan penelitian ini untuk mengetahui korelasi imunoekspresi p53 dengan respons kemoterapi neoadjuvan FAS. Penelitian ini merupakan penelitian analitik potong lintang terhadap 40 kasus KDPI yang diberikan KN FAS di Rumah Sakit Dr. Hasan Sadikin Bandung periode Maret 2008-Februari 2009. Respons KN FAS dinilai berdasarkan ukuran massa tumor setelah pemberian FAS. Blok parafin penderita dibuat pulasan hematoksilin-eosin dan imunohistokimia dengan menggunakan mouse monoclonal antibody p53 protein (Novocastra), kemudian ditentukan tingkat imunoekspresi $p 53$. Uji statistik dengan Somers'd dan Gamma untuk menguji korelasi antar variabel. Nilai $p<0,05$ secara statistik dianggap bermakna. Pada 40 kasus KDPI, 20 berespons dan 20 kasus tidak berespons terhadap KN FAS; 13 kasus terekspresi $p 53>75 \%, 14$ kasus $p 53=10-75 \%, 7$ kasus $p 53<10 \%$, dan 6 kasus tidak terekspresi p53. Terdapat korelasi bermakna antara imunoekspresi $p 53$ dan respons kemoterapi FAS $(\mathrm{p}=0,000)$. Simpulan, semakin tinggi ekspresi $p 53$, semakin tidak berespons terhadap KN FAS. Imunoekspresi $p 53$ dapat memprediksi respons KN FAS pada KDPI stadium IIIB. [MKB. 2012;44(1):13-8].
\end{abstract}

Kata kunci: Karsinoma duktus payudara invasif, imunoekspresi, p53

\section{Correlation between p53 Immunoexpression and Fluorouracyl, Adriamycin and Cyclophosphamide Regimen Neoadjuvant Chemotherapy Responses in Invasive Ductal Breast Carcinoma}

\begin{abstract}
Invasive ductal breast carcinoma (IDBC) stage IIIB need multimodality treatment. Neoadjuvant chemotherapy (NC) is given to reduce the size and stage of tumor so that surgery can be performed. Neoadjuvant chemotherapy regimens generally used was fluorouracil, adriamycin and cyclophosphamide (FAC). FAC chemotherapy works by damaging deoxyribonucleic acid and induce apoptosis of cancer cells. Abnormalities of proteins or genes associated with apoptosis (p53) is believed to affect the chemotherapy response. This study was purpose to determine correlation between immunoexpression of $p 53$ and response of neoadjuvant FAC chemotherapy in invasive ductal breast carcinoma. The study was a cross sectional analytic study of 40 IDBC cases given FAC NC at Dr. Hasan Sadikin Hospital Bandung between March 2008-February 2009. Response of FAC NC judged on the size of tumor mass following administration of FAC. Haematoxylin-eosin and immunohistochemistry stain using a mouse monoclonal antibody to $p 53$ protein (Novocastra) was made from paraffin blocks of patients, then determined the immunoexpression levels of $p 53$. Somers' $d$ and Gamma statistical were used to test the correlation between variables. The p-value $<0.05$ was considered statistically significant. In 40 IDCB cases, 20 cases were responded and 20 cases did not respond to FAC NC; 13 cases expressed $p 53>75 \%, 14$ cases $p 5310-75 \%, 7$ cases $p 53<10 \%$, and 6 cases were not expresed $p 53$; There was a significant correlation between immunoexpression of $p 53$ and the response of FAC chemotherapy $(\mathrm{p}=0.000)$. In conclusions, the higher expression of $p 53$, the lower response to NC FAC. Immunoexpression of $p 53$ can predict the response of FAC NC on IDBC stage IIIB. [MKB. 2012;44(1):13-8].
\end{abstract}

Key words: Immunoexpression, invasive ductal breast carcinoma, $p 53$

Korespondensi: Muhartono, dr., M.Kes., Sp.PA, Bagian Patologi Anatomi Fakultas Kedokteran Universitas Lampung, jalan Soemantri Brojonegoro 1 Bandar Lampung, telepon (0725) 7525077, mobile 081272358340,

e-mail dmuhartono@yahoo.com 


\section{Pendahuluan}

Karsinoma payudara merupakan tumor ganas yang berasal dari epitel duktus terminal payudara. Karsinoma duktus payudara invasif (KDPI) merupakan jenis yang paling banyak ditemukan sebesar $65-80 \%$ pada semua karsinoma payudara. ${ }^{1,2}$

Lebih dari 1.000.000 kasus baru didiagnosis KDPI setiap tahun. DiAmerika Serikat, diperkirakan terdapat 192.200 kasus KDPI baru pada tahun 2001. Pada tahun 2004 terdapat 215.990 kasus KDPI baru. Kurang lebih 75\% penderita KDPI berusia lebih dari 50 tahun dan kurang dari 5\% yang berusia di bawah 40 tahun. $^{3}$

Berdasarkan Badan Registrasi Kanker Ikatan Ahli Patologi Indonesia, karsinoma payudara menduduki peringkat ke-2 dalam urutan 10 kanker terbanyak pada wanita setelah kanker leher rahim. Kelompok usia 35-64 tahun merupakan kelompok usia yang berisiko tinggi dan puncaknya pada usia 35-45 tahun. ${ }^{4}$

Karsinoma duktus payudara invasif menjadi penyebab kematian ke-2 setelah karsinoma paru. Di Amerika Serikat, lebih dari 40.000 kasus meninggal tiap tahun karena kanker payudara. ${ }^{1,3}$

Di Amerika Serikat, KPDI pada umumnya didiagnosis masih dalam stadium dini, sedangkan di Indonesia lebih sering ditemukan pada stadium lanjut. Kejadian karsinoma duktus payudara invasif lanjut lokal di Indonesia diperkirakan $23 \%$ pada stadium IIIA (operable) dan $40 \%$ pada stadium IIIB (inoperable). ${ }^{3}$

Penanganan KDPI lanjut lokal inoperable (stadium IIIB) saat ini dilakukan dengan pemberian kemoterapi neoadjuvan. Pemberian kemoterapi neoadjuvan tersebut bertujuan untuk memperkecil massa tumor dan menghambat mikrometastasis sehingga berpotensi menurunkan stadium menjadi stadium yang operable. ${ }^{5}$

Regimen kemoterapi fluororasil, adriamisin, dan siklofosfamid (FAS) digunakan sebagai standar kemoterapi neoadjuvan pada KDPI lanjut lokal inoperable. Pemberian kemoterapi neoadjuvan akan memperbaiki prognosis penderita dengan angka ketahanan hidup lima tahun sebesar 44-88\%. ${ }^{5}$

Pada dasarnya regimen kemoterapi FAS dapat menyebabkan lesi pada deoxyribonucleic acid (DNA) melalui mekanisme yang berbeda. Lesi tersebut akan menyebabkan kerusakan inti (DNA). Kerusakan DNA yang tidak dapat diperbaiki dapat menginduksi apoptosis. ${ }^{5,6}$

Gen p53 berfungsi untuk memperbaiki DNA dan menginduksi apoptosis. Kerusakan DNAakibat pemberian kemoterapi FAS akan merangsang p53 menginduksi apoptosis. Pada keganasan dengan mutasi $p 53$ dapat menyebabkan regulasi apoptosis terganggu. Mutasi p53 dapat berpengaruh buruk pada respons kemoterapi. ${ }^{6-9}$
Beberapa penelitian menyimpulkan bahwa mutasi p53 dapat memprediksi respons kemoterapi dihubungkan dengan berbagai agen kemoterapi. ${ }^{9}$ Penelitian lain menyatakan mutasi p53 tidak dapat menunjukkan hubungan yang bermakna dengan respons kemoterapi. ${ }^{10}$ Tujuan penelitian ini untuk mengetahui korelasi antara tingkat imunoekspresi p53 dan respons kemoterapi neoadjuvan FAS pada KDPI stadium IIIB.

\section{Metode}

Penelitian dilakukan secara potong lintang pada penderita KDPI stadium IIIB yang mendapat pengobatan neoadjuvan kemoterapi FAS di RS Dr. Hasan Sadikin Bandung selama periode Maret 2008-Februari 2009. Penderita diamati ukuran tumornya setelah terapi neoadjuvan kemoterapi FAS. Blok parafin jaringan karsinoma payudara dilakukan pewarnaan hematoxilin eosin (HE) dan imunohistokimia p53. Pulasan imunohistokimia dengan menggunakan metode labelled streptavidin biotin immunoperoxidase complex, menggunakan novostain universal detection kit (NCL-RTU-D) (Novocastra, Inggris). Antibodi primer yang dipergunakan monoclonal mouse antibody p53 protein clone DO-7 (Novocastra, Inggris). Hasil pulasan inti sel tumor berwarna coklat dengan latar belakang jaringan ikat fibrokolagen berwarna biru keunguan. Sebagai kontrol positif digunakan karsinoma urotelial yang telah diketahui positif dengan anti-p53 antibodi monoklonal. Kontrol negatif dengan menggunakan sediaan KDPI yang sama dengan mengganti antibodi primer dengan serum normal/protein baseline serum (PBS). Kriteria respons kemoterapi terdiri atas berespons dan tidak berespons. Kemoterapi berespons bila terjadi penurunan ukuran tumor primer $\geq 50 \%$ ukuran semula; sedangkan tidak berespons bila terjadi penurunan ukuran tumor primer $<50 \%$ dibandingkan ukuran semula. Imunoekspresi $p 53$, tingkat imunoekspresi $p 53$ dibagi menjadi skala 0 , 1, 2, dan 3. Skala 0, jika seluruh sel tumor negatif; skala 1 , jika $<10 \%$ sel tumor positif lemah; skala 2, jika terdapat kelompok multifokal sel-sel tumor yang terwarnai uniform sebanyak 10-75\%; skala 3 , jika pulasan positif difus $>75 \%$. $^{6,8}$

Analisis data dilakukan dengan menggunakan uji statistik nonparametrik Somers'd dan Gamma yang bertujuan untuk mengevaluasi korelasi antar variabel. Kekuatan korelasi variabel ditentukan dengan cara menghitung koefisien korelasinya. Data akan dievaluasi dan dihitung dengan rumus SPSS versi 11.5. Variabel-variabel penelitian ini berupa variabel katagorik ordinal. Jenis hipotesis adalah korelatif dengan nilai $\mathrm{p}<0,05$ bermakna secara statistik. 


\section{Hasil}

Selama periode Maret 2008-Februari 2009 di Rumah Sakit Dr. Hasan Sadikin Bandung terkumpul 52 kasus yang didiagnosis sebagai KDPI stadium IIIB dan mendapat kemoterapi neoadjuvan FAS, tetapi hanya 40 kasus yang memenuhi kriteria inklusi penelitian (tersedia blok parafin).

Hasil pengamatan imunoekspresi $p 53$, terdapat tujuh kasus $(17,5 \%)$ tidak terekspresi (skala 0), enam kasus (15\%) terekspresi $<10 \%$ (skala 1), 14 kasus (35\%) terekspresi 10-75\% (skala 2), dan 13 kasus (32,5\%) terekspresi $>75 \%$ (skala 3 ). Imunoekspresi p53 positif ditemukan sebanyak 27 kasus (68\%) dan tingkat imunoekspresi $p 53$ negatif ditemukan sebanyak 13 kasus (32\%). Dilakukan pemeriksaan tingkat imunoekspresi p53 pada penderita KDPI stadium IIIB (Tabel 2).

Pada penelitian ini, penderita KDPI mendapat kemoterapi neoadjuvan FAS selama tiga siklus. Pada 40 kasus yang diteliti, sebanyak 20 kasus $(50 \%)$ dengan respons baik atau berespons $(\mathrm{R})$ dan sebanyak 20 kasus (50\%) dengan respons buruk atau tidak berespons (TR).

Tabel 1 Karakteristik Penderita KDPI Stadium IIIB

\begin{tabular}{lrc}
\hline \multicolumn{1}{c}{ Karakteristik } & Jumlah & \% \\
\hline Usia (tahun) & 11 & 28 \\
$\quad<40$ & 9 & 22 \\
$40-49$ & 20 & 50 \\
$\geq 50$ & & \\
$\quad$ Standar deviasi rata-rata: 47,9 (9,0) & & \\
$\quad$ Nilai tengah: 49,5; Rentang: 34-68 & & 45 \\
Ukuran tumor (cm) & 18 & 43 \\
5-9 & 17 & 12 \\
$10-14$ & 5 & \\
$\geq 15$ & & 35 \\
Standar deviasi rata-rata: $10,2(3,3)$ & & 65 \\
Nilai tengah: $10 ;$ Rentang: 5-20 & & \\
Status nodal (KGB) & 14 & \\
N1 & 26 & \\
N2 & & \\
\hline
\end{tabular}

Tabel 2 Hasil Pemeriksaan Tingkat Imunoekspresi p53 Penderita KDPI Stadium IIIB

\begin{tabular}{ccc}
\hline \multicolumn{1}{c}{ Imunoekspresi $\mathbf{p 5 3}$} & Jumlah & \% \\
\hline Negatif $(<10 \%)$ & 13 & 32 \\
Skala 0 $(0 \%)$ & 7 & 17 \\
Skala 1 $(<10 \%)$ & 6 & 15 \\
Positif $(\geq 10 \%)$ & 27 & 68 \\
Skala 2 $(10-75 \%)$ & 14 & 35 \\
Skala 3 $(>75 \%)$ & 13 & 33 \\
\hline
\end{tabular}
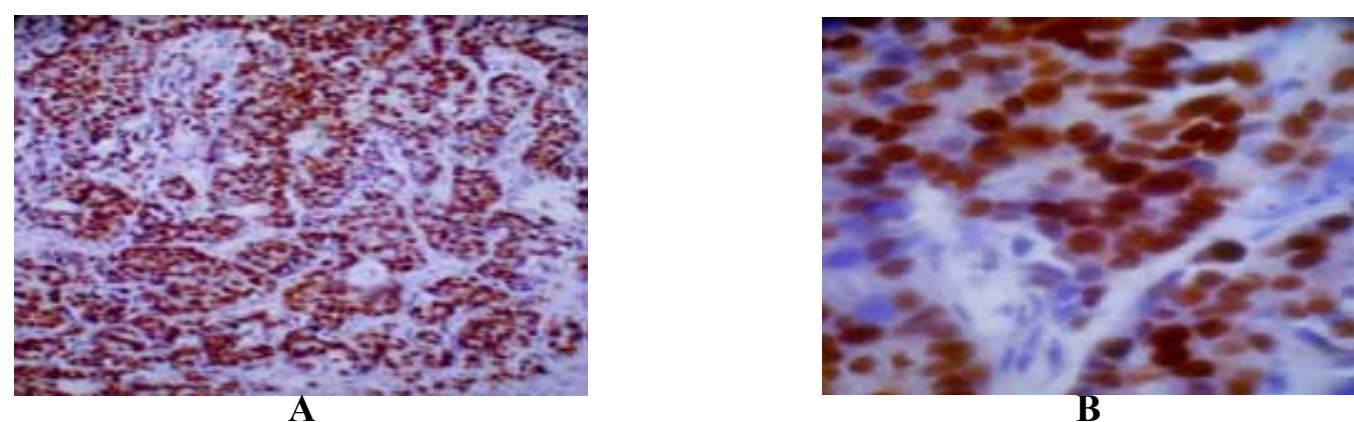

Gambar 1 Pulasan Imunohistokimia $p 53$ pada KPDI yang Terekspresi $>75 \%$ dengan Pembesaran 100x (A) dan 400x (B) 


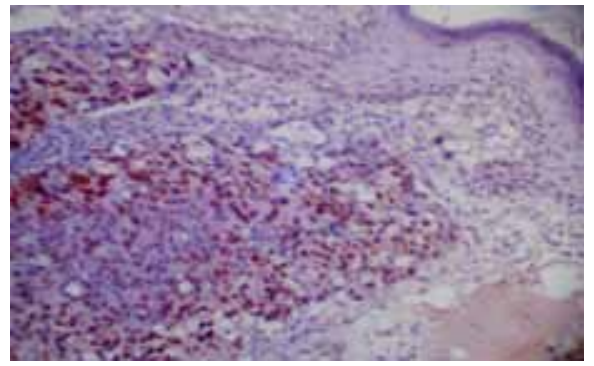

A

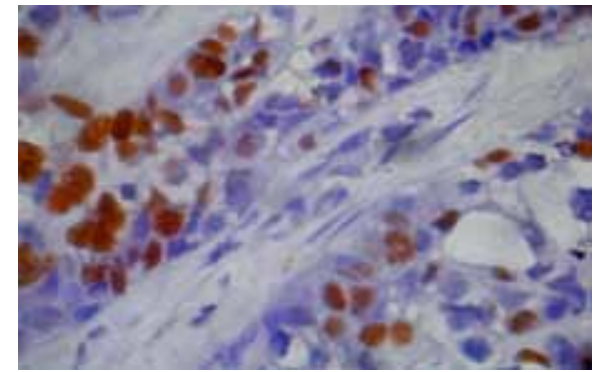

B

Gambar 2 Pulasan Imunohistokimia 53 pada KPDI yang Terekspresi 10-75\% dengan Pembesaran 100x (A) dan 400x (B)

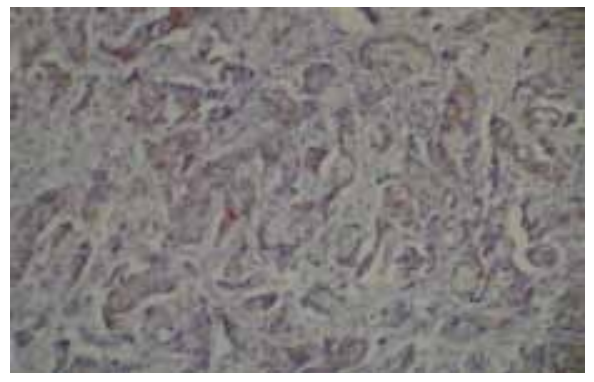

A

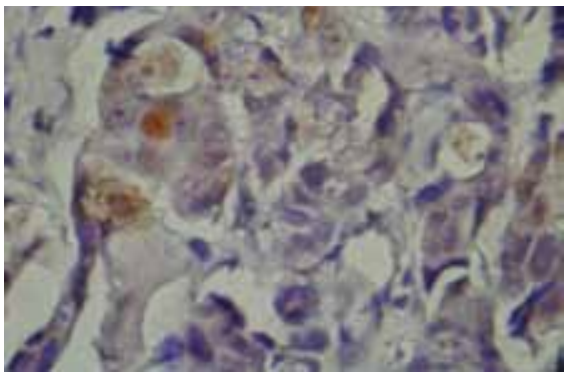

B

Gambar 3 Pulasan Imunohistokimia 53 pada KPDI yang Terekspresi $<10 \%$ dengan Pembesaran 100x (A) dan 400x (B)

Untuk menguji hipotesis penelitian tersebut maka tingkat imunoekspresi p53 dibagi menjadi 4 kelompok yaitu imunoekspresi $p 53$ skala 0 , skala 1, skala 2, dan skala 3. Tingkat respons kemoterapi neoadjuvan FAS dibagi dalam dua kelompok, yaitu berespons dan tidak berespons. Berdasarkan pengelompokan tersebut tingkat respons kemoterapi neoadjuvan FAS dan tingkat imunoekspresi $p 53$, menggunakan perangkat lunak SPSS Ver. 11.5, hasil pengujian statistik dengan uji Somers'd diperoleh nilai $\mathrm{p}=0,000(\mathrm{p}<0,05)$ dengan arah korelasi negatif (Tabel 3). Terdapat korelasi yang bermakna antara tingkat imunoekspresi $p 53$ dan tingkat respons kemoterapi neoadjuvan FAS, yaitu semakin tinggi tingkat imunoekspresi $p 53$, semakin tidak berespons terhadap kemoterapi neoadjuvan FAS.

\section{Pembahasan}

Pada penelitian ini, KDPI stadium IIIB lebih sering ditemukan pada kelompok usia di atas 50 tahun, yaitu sebesar $50 \%$. Usia rata-rata penderita

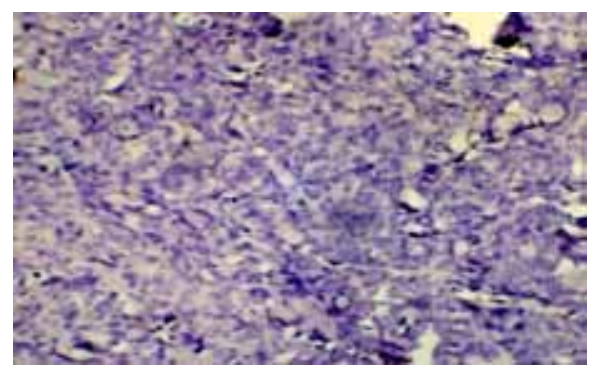

A

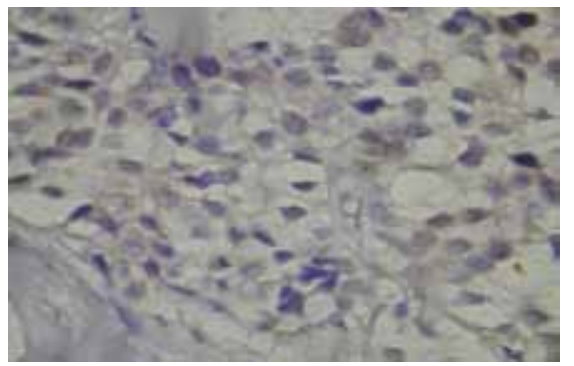

B

Gambar 4 Pulasan Imunohistokimia p53 pada KPDI yang Terekspresi 0\% dengan Pembesaran 100x (A) dan 400x (B) 
Muhartono: Korelasi antara Imunoekspresi p53 dan Respons Kemoterapi Neoadjuvan Regimen Fluororasil

Tabel 3 Korelasi antara Tingkat Imunoekspresi p53 dan Tingkat Respons Kemoterapi Neoadjuvan FAS

\begin{tabular}{cccc}
\hline \multirow{2}{*}{ Imunoekspresi $\mathbf{p 5 3}$} & \multicolumn{2}{c}{ Respons Kemoterapi } & Kemaknaan \\
\cline { 2 - 3 } & $\begin{array}{c}\text { Tidak berespons } \\
(\mathbf{n}=\mathbf{2 0})\end{array}$ & $\begin{array}{c}\text { Berespons } \\
(\mathbf{n}=\mathbf{2 0})\end{array}$ & $\mathrm{p}=0,000$ \\
1 & 1 & 6 & $\mathrm{r}=-0,628$ \\
2 & 2 & 9 & 1 \\
\hline
\end{tabular}

Keterangan: nilai $\mathrm{p}<0,05$ secara statistik bermakna; r, kekuatan korelasi; +/-, arah korelasi

KPDI adalah 47,9 tahun dan nilai tengah usia 49,5 tahun. Usia paling muda 34 tahun, sedangkan usia paling tua 68 tahun.

Rentang usia penderita KPDI lanjut lokal 29-70 tahun dengan nilai tengah usia 47 tahun. Karsinoma payudara sangat jarang ditemukan pada usia di bawah 20 tahun, dan insidensinya meningkat seiring dengan bertambahnya usia. Risiko karsinoma payudara pada usia 30-40 tahun 1:252, usia 40-50 tahun 1:68, dan usia 60-70 tahun $1: 27$. Lebih dari $77 \%$ karsinoma payudara terjadi di atas usia 50 tahun dan usia rata-rata pada saat didiagnosis 64 tahun. ${ }^{1-3,6,7}$

Di Indonesia kelompok usia 35-64 tahun merupakan kelompok usia yang berisiko tinggi dan puncaknya pada usia 35-45 tahun. Di Bandung karsinoma payudara menduduki peringkat ke-2 setelah karsinoma leher rahim dengan distribusi usia 25-34 tahun, 35-44 tahun, 45-54 tahun, 5564 tahun, dan lebih dari 65 tahun masing-masing sebanyak 6, 18, 20, 15, dan 9 kasus. $^{4}$

Pada penelitian ini, ukuran massa tumor sebelum dilakukan kemoterapi terbagi menjadi tiga kelompok, yaitu diameter 5-9 cm, 10-14 cm, dan di atas $14 \mathrm{~cm}$. Ukuran 5-9 $\mathrm{cm}$ dan $10-14 \mathrm{~cm}$ paling banyak. Rentang ukuran adalah $5-20 \mathrm{~cm}$, ukuran massa tumor rata-rata 10,2 cm. Beberapa kepustakaan menyatakan hal yang hampir sama, yaitu ukuran tumor $\leq 10 \mathrm{~cm}$ sebanyak $64,5 \%$, sedangkan $>10 \mathrm{~cm}$ sebanyak $35,5 \%$ pada KDPI lanjut lokal. ${ }^{3,6,7}$

Pada penelitian ini, imunoekspresi p53 positif lebih banyak daripada imunoekspresi negatif. Beberapa kepustakaan menunjukkan imunoekspresi p53 positif sebanyak 49\% dan negatif $51 \%$ kasus karsinoma yang mengalami kegagalan terapi mastektomi. Imunoekspresi p53 positif ditemukan $60 \%$ dan imunoekspresi p53 negatif 40\% dari kasus karsinoma payudara inflamatori. ${ }^{9,11}$

Pada 40 kasus yang diteliti, sebanyak 20 kasus (50\%) mempunyai respons yang baik (berespons), sedangkan 20 kasus lainnya (50\%) mempunyai respons yang buruk (tidak berespons). Pada umumnya kasus yang diberikan kemoterapi neoadjuvan mempunyai respons terapi yang baik, sebanyak 10-20\% mempunyai respons lengkap, $50-60 \%$ mempunyai respons sebagian, dan hanya $20-40 \%$ mempunyai respons stabil atau progresif. Pada penelitian ini mempunyai respons terapi yang lebih buruk (50\% tidak berespons), karena penelitian ini dilakukan pada stadium lanjut lokal (IIIB). Menurut Ross dan Herbeck, ${ }^{12}$ respons kemoterapi dipengaruhi oleh stadium, ukuran tumor, status nodal, dan derajat keganasan.

Pengobatan kemoterapi FAS mempunyai mekanisme yang berbeda yang akan berakhir pada kematian sel akibat apoptosis. Kegagalan apoptosis diperkirakan dapat menyebabkan kemoresisten. ${ }^{13}$

Mutasi p53 akan menyebabkan akumulasi protein p53 pada inti sel. Fungsi p53 untuk mengatur siklus sel dan induksi apoptosis. Dalam peranannya menginduksi apoptosis, p53 akan menghambat $\mathrm{Bcl}-2$, sebaliknya akan menginduksi Bax. Data preklinis menunjukkan bahwa sel yang mempunyai mutasi p53 akan resisten terhadap stimuli apoptosis kemoterapi. ${ }^{14,15}$

Pada penelitian ini didapatkan imunoekspresi p53 positif sebanyak 27 kasus dari 40 kasus $(68 \%)$ dan 13 kasus (32\%) mempunyai imunoekspresi $p 53$ negatif. Terdapat korelasi yang bermakna antara tingkat imunoekspresi p53 dan tingkat respons kemoterapi neoadjuvan FAS $(p=0,000)$. Semakin tinggi tingkat imunoekspresi $p 53$, semakin tidak berespons terhadap kemoterapi neoadjuvan FAS.

Kemoterapi FAS melalui mekanisme yang berbeda menyebabkan kerusakan DNA. Kerusakan DNA yang tidak dapat diperbaiki menyebabkan p53 menginduksi apoptosis. Respons terhadap kombinasi FAS secara langsung berkaitan dengan fungsi p53 dan apoptosis pada karsinoma payudara. Efek sitotoksik FAS bergantung pada status $p 53 .{ }^{15,16}$ Penderita dengan overekspresi $p 53$ atau mutasi $p 53$ sebaiknya diberikan kemoterapi yang tidak bergantung pada induksi p53 seperti paclitaxel. ${ }^{17}$

Kejadian mutasi p53 pada karsinoma payudara dihubungkan dengan sifat agresif dan buruknya ketahanan hidup. Mutasi p53 akan menyebabkan gangguan stabilitas serta integritas genom, sel 
akan terus berproliferasi, dan gagalnya apoptosis. Mekanisme kerja kemoterapi itu akhirnya akan menginduksi apoptosis, sehingga mutasi $p 53$ dapat menyebabkan resistensi terhadap kemoterapi. . $^{14,15}$

Beberapa penelitian menghubungkan antara imunoekspresi p53 dan regimen kemoterapi yang berbeda. Respons kemoterapi yang buruk terjadi pada kasus KPDI lanjut lokal dengan mutasi $p 53$ yang diberikan FAS. Overekspresi $p 53$ berhubungan dengan respons yang buruk terhadap doxorubicin pada penderita karsinoma payudara. Mutasi $p 53$ dapat digunakan untuk memprediksi resistensi terhadap kemoterapi. ${ }^{15,16}$

Saat ini dikembangkan terapi target terhadap mutasi $p 53$. Kehilangan fungsi $p 53$ yang dihasilkan dari mutasi dapat dicegah dengan pemberian $p 53$ reactivation and induction massive of apoptosis-1 (PRIMA-1). p53 reactivation and induction massive of apoptosis-1 memperbaiki interaksi p53-

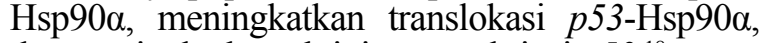
dan meningkatkan aktivitas transkrispi $p 53 .^{18}$

Simpulan, semakin tinggi tingkat imunoekspresi $p 53$, semakin tidak berespons terhadap kemoterapi neoadjuvan FAS pada KDPI stadium IIIB. Sebaiknya dihindarkan kemoterapi neoadjuvan FAS, bila diketahui terdapat imunoekspresi $p 53$ tinggi pada KDPI stadium IIIB.

\section{Daftar Pustaka}

1. Ellis IO, Schnitt SJ, Sastre-Garau X, Bussolati G, Tavassoli FA, Eusebi V, dkk. Invasive breast carcinoma. Dalam: Tavassoli FA, Devilee $P$, penyunting. Pathology and genetics of tumours of the breast and female genital organs. Lyon: IARC Press; 2003. hlm. 13-59.

2. Rosen PP. Rosen's breast pathology. Edisi ke-2. Philadelphia: Lippincott Williams and Wilkins; 2001.

3. Wood WC, Muss HB, Solin LJ, Olopade OI. Malignant tumor of the breast. Dalam: DeVita VT, Hellman S, Rosenberg SA, penyunting. Cancer principle and practice of oncology. Edisi ke-7. Philadelphia: Lippincott Williams and Wilkins; 2006. hlm. 1415-71.

4. Badan Registrasi Kanker Perhimpunan Dokter Spesialis Patologi Indonesia (BRK). Kanker di Indonesia tahun 1999 data histopatologik. Jakarta: Direktorat Jendral Pelayanan Medik Departemen Kesehatan RI; 1999.

5. Moon YW, Rha SY, Jeung HC, Yang WI, Suh CO, Chung HC. Neoadjuvant chemoteraphy with infusional 5-fluorourasil, adriamycin, and cyclophosphamide (iFAC) in locally advanced breast cancer: an early response predicts good prognosis. Annals Oncol. 2005;16:1778-85.

6. Rosai J. Rosai and Ackerman's surgical pathology. Edisi ke-9. Edinburgh: Mosby; 2004.

7. Kumar V, Abas AK, Fausto N. Robbins and Cotran pathologic basis of disease. Edisi ke-7. Philadelphia: Elsevier Saunders; 2005.

8. Borresen-Dale AL. $p 53$ review article, TP53 and breast. Human Mut. 2003;21:292-300.

9. Oliveira AM, Ross JS, Fletcher JA. p53 and tumor suppressor genes in breast cancer. Dalam: Ross JF, Hortobagyi GN, penyunting. Moleculer oncology of the breast cancer. Boston: Jones and Bartlett Publ; 2005.

10. Munster PN, Norton L. Predictive factor the response to adjuvant therapy with emphasis in breast cancer. Breast Cancer Res. 2001;3:3614.

11. Anderson J, Larsson L, Klaar S, Holmberg L, Nilsson J, Iganas M, dkk. Worse survival for TP53 ( 553$)$-mutated breast cancer patients receiving adjuvant CMF. Annals Oncol. 2005;16:743-8.

12. Ross JS, Herbeck N. Prognosic and predictive factors overview. Dalam: Ross JF, Hortobagyi $\mathrm{GN}$, penyunting. Moleculer oncology of the breast cancer. Boston: Jones and Bartlett Publ; 2005. hlm. 1-11.

13. Esteva FJ, Hortobagyi GN. Integration of systemic chemotherapy in the management of primary breast cancer. Oncologist. 1998; 3:300-13.

14. Munster PN, Norton L. Predictive factor the response to adjuvant therapy with emphasis in breast cancer. Breast Cancer Res. 2001;3:3614.

15. Gasco M, Shami S, Crook T. The p53 pathway in breast cancer. Breast Cancer Res. 2002;4:70-6.

16. Barret-Lee PJ. Growth factor signaling in clinical breast cancer and its impact on response to convensional therapies: a review of chemotherapy. Endocrine-rel. Cancer. 2005;12:125-33.

17. Anelli A, Brentani RR, Gadelha AP, de Albuquerque AA, Soares F. Correlation of p53 status with outcome of neoadjuvant chemotherapy using paclitaxel and doxorubicin in stage IIIB breast cancer. Annal Oncol. 2003; 14:428-32.

18. Rehman A, Chahal MS, Tang X, Bruce JE, Prommier Y, Daoud SS. Proteomic identification of heat shock protein 90 as a candidate target for $p 53$ mutation reactivation by PRIMA-1 in breast cancer cell. Breast Cancer Res. 2005;7:R765-74. 